\title{
Attractive and feeding stimulative effect of some fatty acids and related compounds on three species of cockroaches
}

\author{
By
}

Hideakira Tsuji ${ }^{11}$

\section{INTRODUCTION}

In a previous paper (Tsuji, 1965), it has been already reported that rice bran which the cockroaches feed by preference contains fat soluble substances acting as olfactory attractants, and methanol or water soluble substances and fat soluble ones acting as feeding stimulants. Several sugars and some related compounds have also been shown to be gustatory feeding stimulants, although regarding the fat soluble attractants and feeding stimulants no identifications have been attempted. Noguchi (1961) reported that oleic acid had a feeding stimulative effect on Periplaneta fuliginosa and Blattella germanica. Ogata and Mihara (1962) obtained a result that suggested oleic acid was significantly attractive for $B$. germanica. They also tested some other acids but could not obtain any clear cut results.

The present report gives a brief survey of both of the attractive and feeding stimulative effect of some fatty acids, their esters, and related alcohols including those which are not the constituents of rice bran.

\section{MAterials AND METHODS}

The cockroaches used were Periplaneta americana Linné, $P$. fuliginosa Serville, and Blattella germanica (Linné); these had been reared in the laboratory throughout the year by the same method as described in the previous paper (Tsuji, 1965).

A mixed population of several starved adults and nymphs was used in the assay of each species. The insects were kept, in a glass box $(46 \mathrm{~cm} \times 21 \mathrm{~cm} \times 31 \mathrm{~cm})$ with one or two wooden shelter boxes $(12.5 \mathrm{~cm} \times 12.5 \mathrm{~cm} \times 10.0 \mathrm{~cm}$, with

1) 辻 英明: Agricultural Chemicals Research Laboratories, Sankyo Co., Ltd., Hiromachi, Shinagawa-ku, Tokyo several shelves) in which they usually hid themselves, and a filter paper impregnated with each compound to be tested was placed on the shelter (Fig. 1) or at the bottom of the container. The insects were supplied with enough water during the experiments.

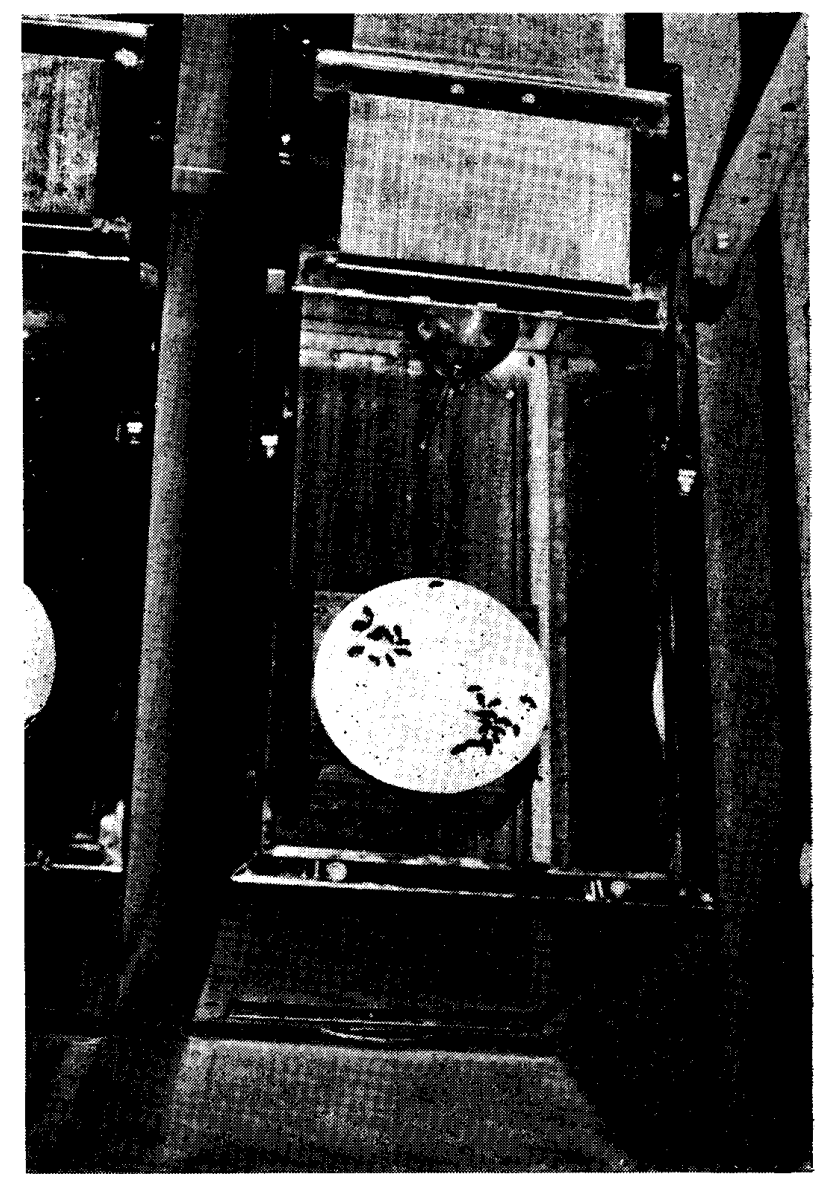

Fig. 1 A filter paper placed on the shelter in the container of cockroaches

In testing the attractive effect of each compound (Tokyo Chemical Industry Co., Ltd., Tokyo), it was expected that attractive compounds did not necessarily have an arrestant effect for the cockroaches (Detheir, 1960, Tsuji, $1965)$, so the filter paper $(12.5 \mathrm{~cm}$ diameter) was previously given four spots of a mixture of carbohydrates, which had keen shown 


$$
\text { 衛 生 動 物 }
$$

(Tsuji, 1965) to be effective in arresting the cockroaches through eliciting their biting response, but not to be effective in causing the insects to make oriented movements towards the spots. L-arabinose, galactose, sorbitol, maltose, fructose, and sucrose of the same weight were mixed in a tube, and about $25 \mu \mathrm{l}$ aliquot of $10 \%$ aqueous solution of the mixture was dropped with a pipet at each of four points on the paper. After leing dried, two of the four pretreated spots treated with a compound to be tested. Each compound tested was diluted with acetone or chloroform in two concentrations of $10 \mathrm{mg} / \mathrm{ml}$ and $1 \mathrm{mg} / \mathrm{ml}$. Akout $25 \mu \mathrm{l}$ of the dilution was dropped on each of the two spots, giving each spot about $250 \mu \mathrm{g}$ or $25 \mu \mathrm{g}$ of the compound. The other two spots were given solvent only. After being dried for 3 minutes, the paper was placed and kept in the container for 15 minutes. All compounds were tested for each species three times at the higher concentration, and some were further tested twice

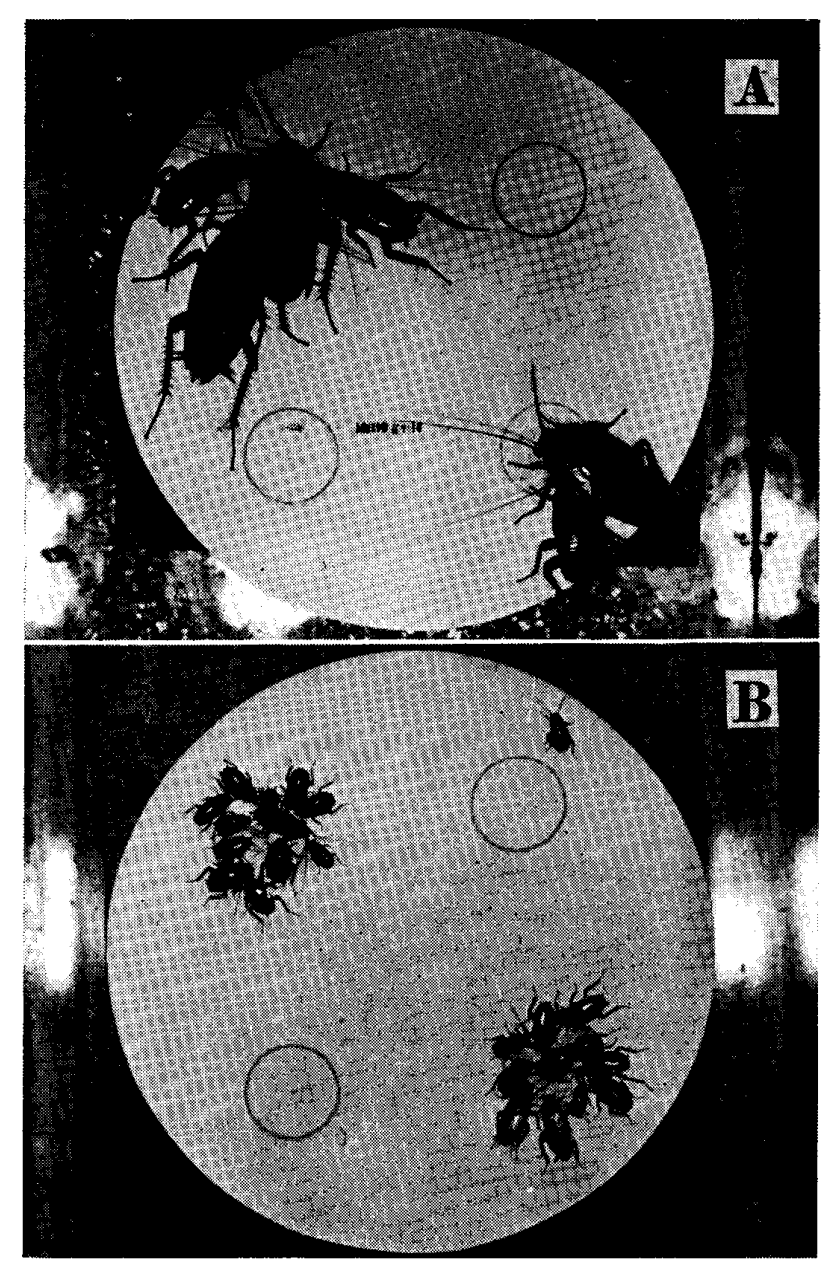

Fig. 2 Insects gathering on the attractive spots (25 $\mu \mathrm{g}$ methyl palmitate per spot)

$P$. americana (A) B. germanica (B) at the lower one. The insects gathered selectively to the two spots treated with the test compound when it was attractive as shown in Fig. 2A and B. They bited the spots with their mandibles responding to the carbohydrates, and left scars on the spots, so the scars could be used as an index of the insect aggregation on the spots (Fig. 3).

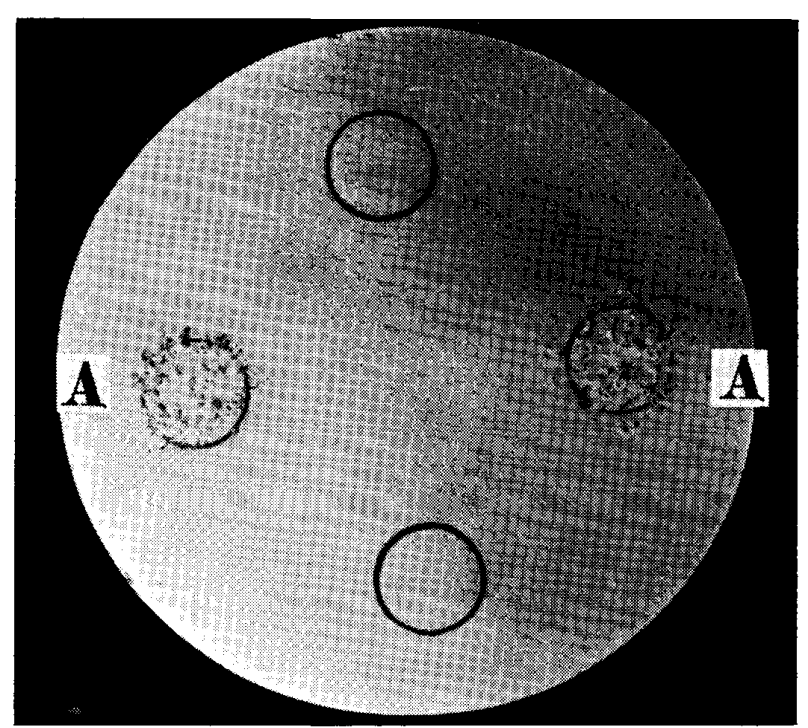

Fig. 3 Attractive spots bitten by $P$. americana (A)

When the feeding stimulative effect of compounds was tested, no pretreatment was given on the paper. In this case, single spots of each compound (about $250 \mu \mathrm{g}$ in each spot) were given on a larger filterpaper $(18.5 \mathrm{~cm}$ diameter), and the paper was kept overnight (for 16 hours or more) in the container of cockroaches in order to give the insects enough time to encounter the spots. This technique is essentially the same as that used in testing the same effect of sugars and other related compounds (Tsuji, 1965).

Other treatments will be stated, when necessary, in the pages of results and discussion. All the assay experiments were done at $25 \pm 2{ }^{\circ} \mathrm{C}$ in a room with the natural day length from $\mathrm{Oc}$ tober to December.

\section{RESULTS AND DISCUSSION}

\section{Periplaneta americana}

The results of the tests for the attractiveness of thirteen acids are shown in Table 1 . The state of the scars on each spot was expressed by two kinds of signs, $(+)$ indicating a heavily 
bitten spot, or a spot not so heavily but definitely bitten, (-) a spot with only a single or

Table 1 Attractiveness of thirteen acids for $P$. americana

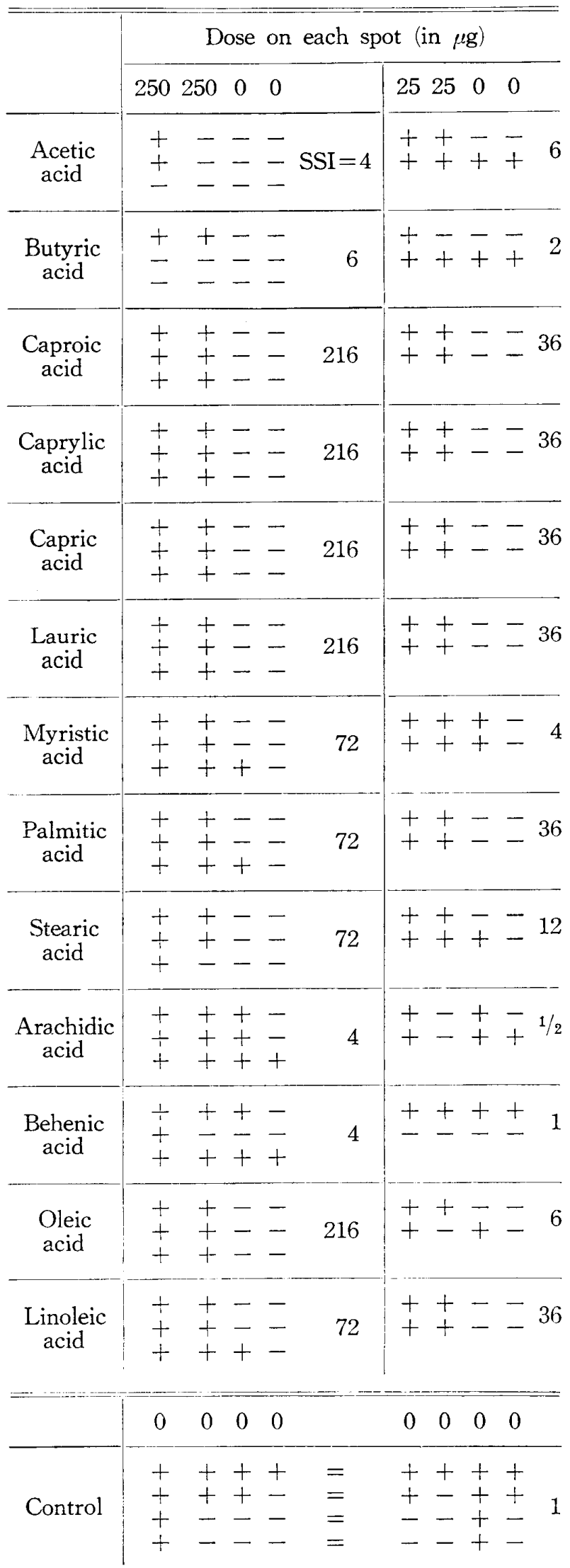

a few trial traces, or with no trace during the testing period.

In order to compare the results in figures, the "spot selection index" (SSI) was calculated from the results of each compound at each concentration as follows.

$\mathrm{SSI}=\mathrm{S}_{1} \times \mathrm{S}_{2} \times \mathrm{S}_{3} \quad$ or $\quad \mathrm{S}_{1} \times \mathrm{S}_{2}$ :

where $S_{1}, S_{2}$, and $S_{3}$ are the reciprocals of the probability in which attractive results occur by chance, or the probability itself where repellent results occur. The neutral results are designed to operate no effect on the calculations. The values in possible results are as follows.

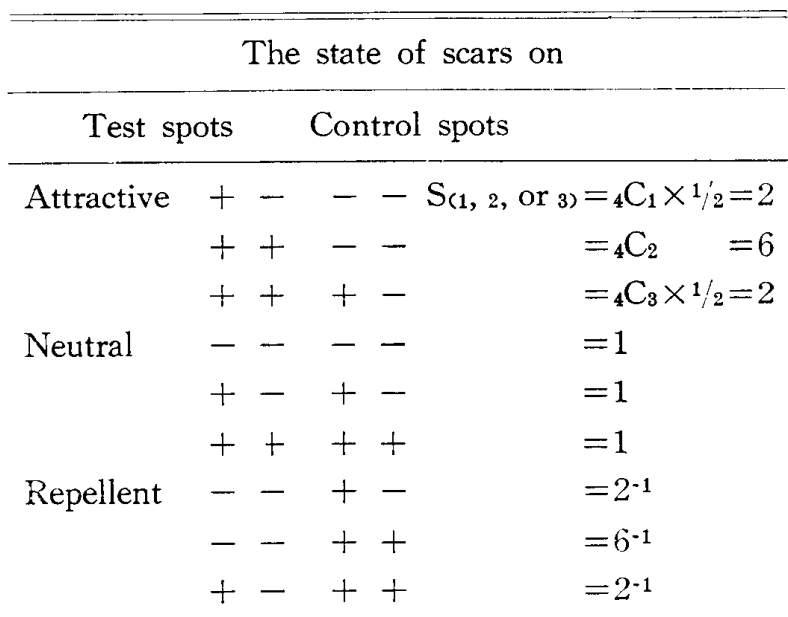

SSI values can be understood as follows.

SSI $>1$ : possibly attractive.

SSI $>20$ : attractive at a significant level.

$\mathrm{SSI}<1$ : possibly repellent.

$\mathrm{SSI}<1 / 20$ : repellent at a significant level.

The indexes of all compounds tested including those of the fatty acids are shown in Table 2 .

The tables show that many of the compounds tested were more or less attractive for this species. Though the tables are not enough to indicate the quickness of the response of the cockroach to the compounds, saturated free fatty acids with a smaller number of carbon atoms (less than 10) were observed to be more effective in quick attraction of the insect than those with much more. This quicker response of the insects was accompanied with too much heavier excitement for them to stay on the spot of $\mathrm{n}$ butyric acid, and more remarkably on that of acetic acid. The acids of too large molecules were less effective, so there was an optimum range of molecular weights of the acids. The most effective acids in gathering the insects on 
Table 2 Attractiveness of the test compounds for $P$. americana

\section{Formula}

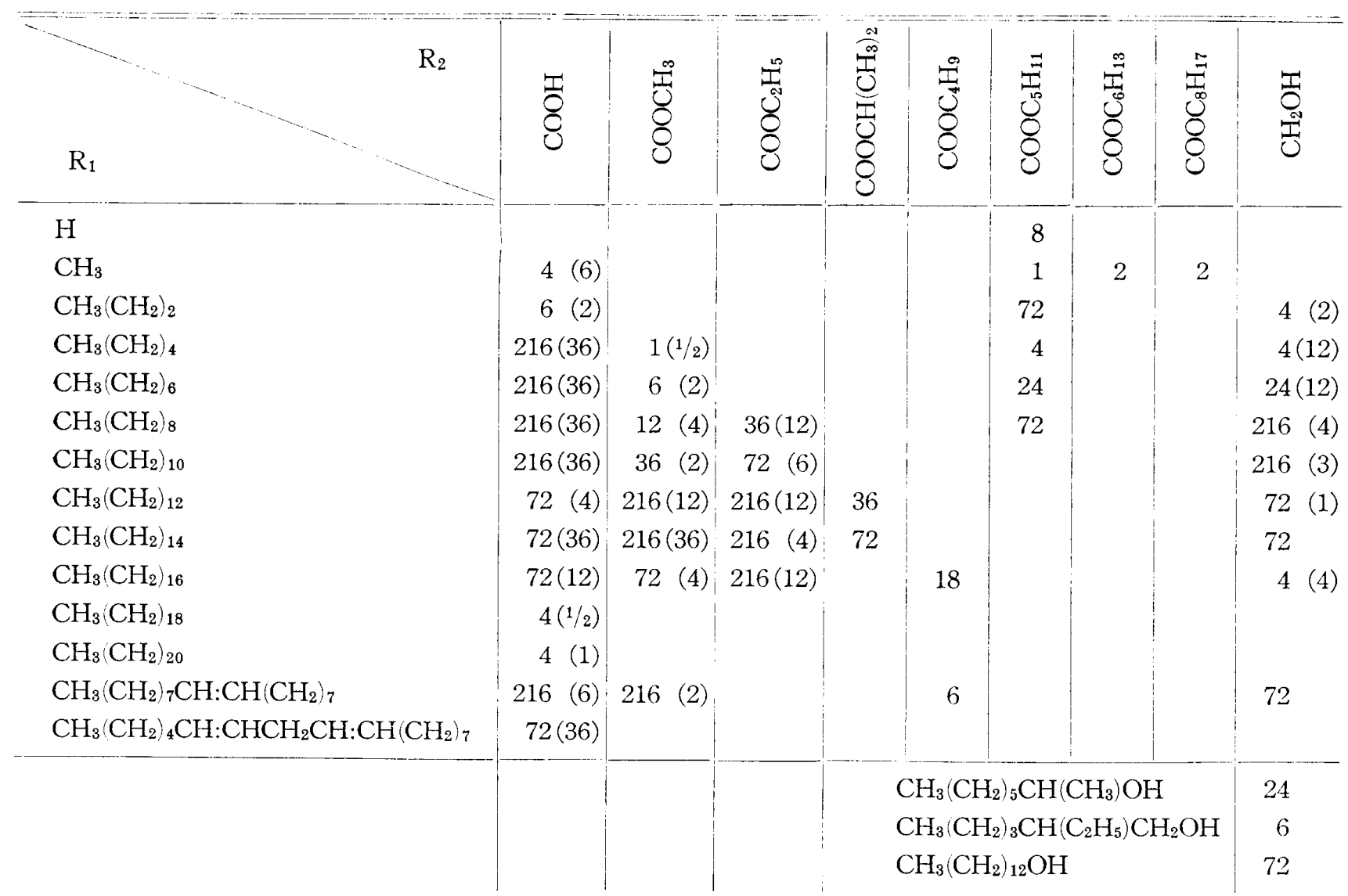

The indexes in parentheses were from the results of two replicates of tests at a dose level of $25 \mu \mathrm{g}$ per spot, and those not in parentheses were of three replicates of tests at a dose level of $250 \mu \mathrm{g}$ per spot.

the spots were n-caproic, n-caprylic, n-capric, and lauric acid. Two unsaturated free fatty acids with 18 carbon atoms were equally or more effective than the saturated one having the same number of carbon atoms.

The optimum ranges were also shown in other groups of compounds. The suitable number of carbon atoms of the fatty acids in methyl, or ethyl esters was greater than that of the free fatty 'acids. Methyl, and ethyl ester of myristic acid, and those of palmitic acid always gave good results. As the number of carbon atoms of alcohol moiety in esters increased, the esters with lower acid moiety became effective. The suitable number of carbon atoms of saturated alcohols dropped between 8 and 14.

The compounds were assayed also for the feeding stimulative effect at a dose level of about $250 \mu \mathrm{g}$ per spot on the paper. The results are shown in Table 3. A few of the attractive compounds showed also the feeding stimulative effect, but many others were less or not effective despite of their long time exposure to the insects. The most effective feeding stimulants were $\mathrm{n}$-caproic acid, $\mathrm{n}$-caprylic acid, n-capric acid, methyl myristate, and ndecyl alcohol. These feeding stimulative compounds, therefore, might be also effective in arresting the insects on the spot, as well as in attracting to it. The feeding stimulative carbohydrates, however, were still quite effective in multiplying the arrestant effect of the spots with these feeding stimulants. For example, the number of insects gathering on the double spot of maltose and methyl myristate, or maltose and caprilic acid was much more greater than the sum on the single spots where the compounds were used separately (Table $4 \mathrm{~A}$ and B). Palmitic acid which had been reported to elicit intense aggregating and feeding responses in Tribolium confusum (Loschiavo, 1965) was also attractive for the cockroach, but was not feeding stimulative at the dose level tested. 
Table 3 Feeding response of $P$. americana to the spots treated with the test compounds Four spots were used per compound.

Formula $\mathrm{R}_{1}-\mathrm{R}_{2}$

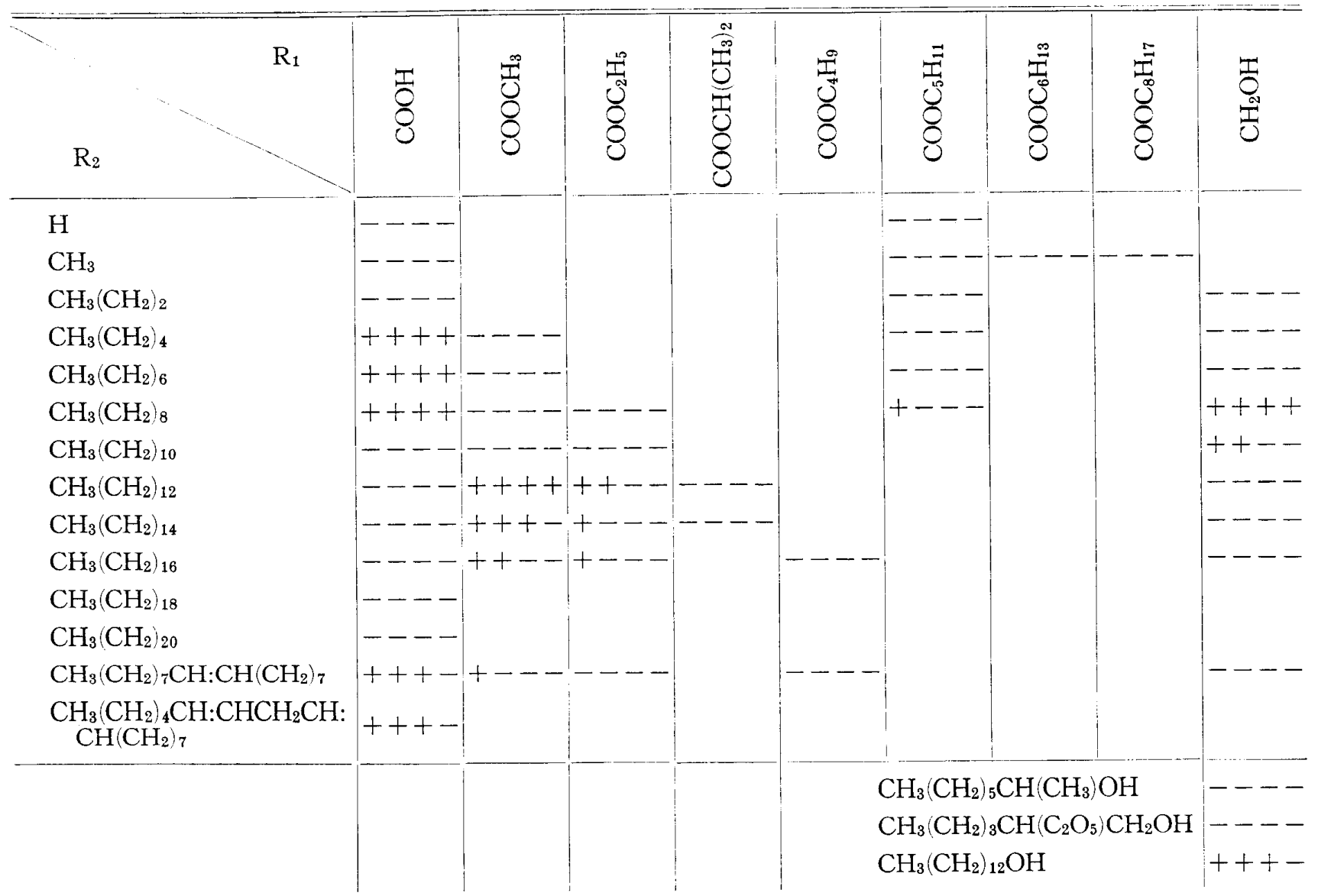

Table 4 The arrestant effect of maltose which multiply the number of insects $(P$. americana) aggregating on the attractive spots

\begin{tabular}{|c|c|c|c|c|c|c|c|}
\hline $\mathrm{A}$ & \multicolumn{3}{|c|}{ Number of insects on the spots of } & B & \multicolumn{3}{|c|}{ Number of insects on the spots of } \\
\hline $\begin{array}{l}\text { Time in } \\
\text { minutes }\end{array}$ & $\begin{array}{l}\text { 1. Maltose } \\
(2.5 \mathrm{mg} \\
\text { per spot })\end{array}$ & $\begin{array}{l}\text { 2. Methyl } \\
\text { myristate } \\
(250 \mu \mathrm{g} \\
\text { per spot })\end{array}$ & $1+2$ & $\begin{array}{l}\text { Time in } \\
\text { minutes }\end{array}$ & $\begin{array}{l}\text { 1. Maltose } \\
\text { (2.5 mg } \\
\text { per spot) }\end{array}$ & $\begin{array}{l}\text { 2. n-Caprylic } \\
\text { acid } \\
(250 \mu \mathrm{g} \\
\text { per spot })\end{array}$ & $1+2$ \\
\hline 5 & 0 & 0 & 3 & 5 & 0 & 1 & 5 \\
\hline 10 & 0 & 2 & 7 & 10 & 0 & 2 & 5 \\
\hline 15 & 0 & 0 & 9 & 15 & 1 & 3 & 6 \\
\hline 20 & 0 & 1 & 10 & 20 & 0 & 1 & 6 \\
\hline
\end{tabular}

Three compositions were compared on a filter paper $(18.5 \mathrm{~cm}$ in diameter $)$ at a time. Number of insects on two spots of an identical composition was recorded every five minutes.

\section{Periplaneta fuliginosa and Blattella ger- manica}

The results obtained with $P$. fuliginosa and $B$. germanica are principally similar to those with $P$. americana as shown in Tables $5,6,7$, and 8 . It is possible, however, that there are some species-specific responses among the three species. The feeding responses of $P$. fuliginosa were somewhat restricted to fewer compounds than the other two species. The $\mathrm{C}_{6}$ and $\mathrm{C}_{8}$ saturated free fatty acid, and the $\mathrm{C}_{8}$ and $\mathrm{C}_{10}$ saturated alcohol were not so attractive for $B$. germanica as they were for the other two species. P. americana did not feed the spot of n-octyl alcohol, but $P$. fuliginosa fed better the spot rather than that of n-decyl alcohol which $P$. americana fed. Further, B. germanica fed 
Table 5 Attractiveness of the test compounds for $P$. fuliginosa

Formula $\mathrm{R}_{1}-\mathrm{R}_{2}$

\begin{tabular}{|c|c|c|c|c|c|c|c|c|c|}
\hline${ }_{2}$ & $\stackrel{T}{8}$ & $\frac{2}{8}$ & $\begin{array}{l}\text { 蛋 } \\
8 \\
8\end{array}$ & 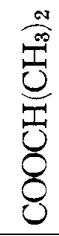 & 8 & $\begin{array}{l}7 \\
8 \\
8 \\
8\end{array}$ & 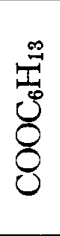 & 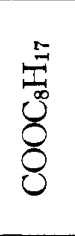 & 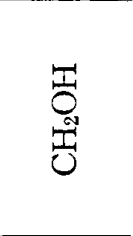 \\
\hline $\begin{array}{l}\mathrm{H} \\
\mathrm{CH}_{3} \\
\mathrm{CH}_{3}\left(\mathrm{CH}_{2}\right)_{2} \\
\mathrm{CH}_{3}\left(\mathrm{CH}_{2}\right)_{4} \\
\mathrm{CH}_{3}\left(\mathrm{CH}_{2}\right)_{6} \\
\mathrm{CH}_{3}\left(\mathrm{CH}_{2}\right)_{8} \\
\mathrm{CH}_{3}\left(\mathrm{CH}_{2}\right)_{10} \\
\mathrm{CH}_{3}\left(\mathrm{CH}_{2}\right)_{12} \\
\mathrm{CH}_{3}\left(\mathrm{CH}_{2}\right)_{14} \\
\mathrm{CH}_{3}\left(\mathrm{CH}_{2}\right)_{16} \\
\mathrm{CH}_{3}\left(\mathrm{CH}_{2}\right)_{18} \\
\mathrm{CH}_{3}\left(\mathrm{CH}_{2}\right)_{20} \\
\mathrm{CH}_{3}\left(\mathrm{CH}_{2}\right)_{7} \mathrm{CH}: \mathrm{CH}\left(\mathrm{CH}_{2}\right)_{7} \\
\mathrm{CH}_{3}\left(\mathrm{CH}_{2}\right)_{4} \mathrm{CH}: \mathrm{CHCH} \mathrm{CH}_{2} \mathrm{CH}\left(\mathrm{CH}_{2}\right)_{7}\end{array}$ & $\begin{array}{r}1 / 6(1) \\
1(1 / 6) \\
72(6) \\
72(36) \\
72(36) \\
72(4) \\
216(12) \\
72(36) \\
72(1) \\
24(1) \\
18(12) \\
216(6) \\
216(2)\end{array}$ & $\begin{array}{r}1(6) \\
24(36) \\
24(4) \\
24(12) \\
216(36) \\
216(6) \\
216(12)\end{array}$ & $\begin{array}{rr}6 & (12) \\
24 & (4) \\
24 & (2) \\
24 & (36) \\
36 & (6) \\
& \\
24 & (6)\end{array}$ & $\begin{array}{l}24 \\
12\end{array}$ & 12 & $\begin{array}{r}6 \\
12 \\
2 \\
2 \\
24 \\
6\end{array}$ & 4 & 12 & $\begin{array}{r}2(1) \\
72(1 / 3) \\
72(6) \\
216(1) \\
72(12) \\
72(36) \\
24 \\
12(12)\end{array}$ \\
\hline & & & & \multicolumn{5}{|c|}{$\begin{array}{l}\mathrm{CH}_{3}\left(\mathrm{CH}_{2}\right)_{5} \mathrm{CH}\left(\mathrm{CH}_{3}\right) \mathrm{OH} \\
\mathrm{CH}_{3}\left(\mathrm{CH}_{2}\right)_{3} \mathrm{CH}\left(\mathrm{C}_{2} \mathrm{H}_{5}\right) \mathrm{CH}_{2} \mathrm{OH} \\
\mathrm{CH}_{3}\left(\mathrm{CH}_{2}\right)_{12} \mathrm{OH}\end{array}$} & $\begin{array}{r}216 \\
2 \\
4\end{array}$ \\
\hline
\end{tabular}

Table 6 Feeding response of $P$. fuliginosa to the spots treated with the test compounds Formula $R_{1}-R_{2}$

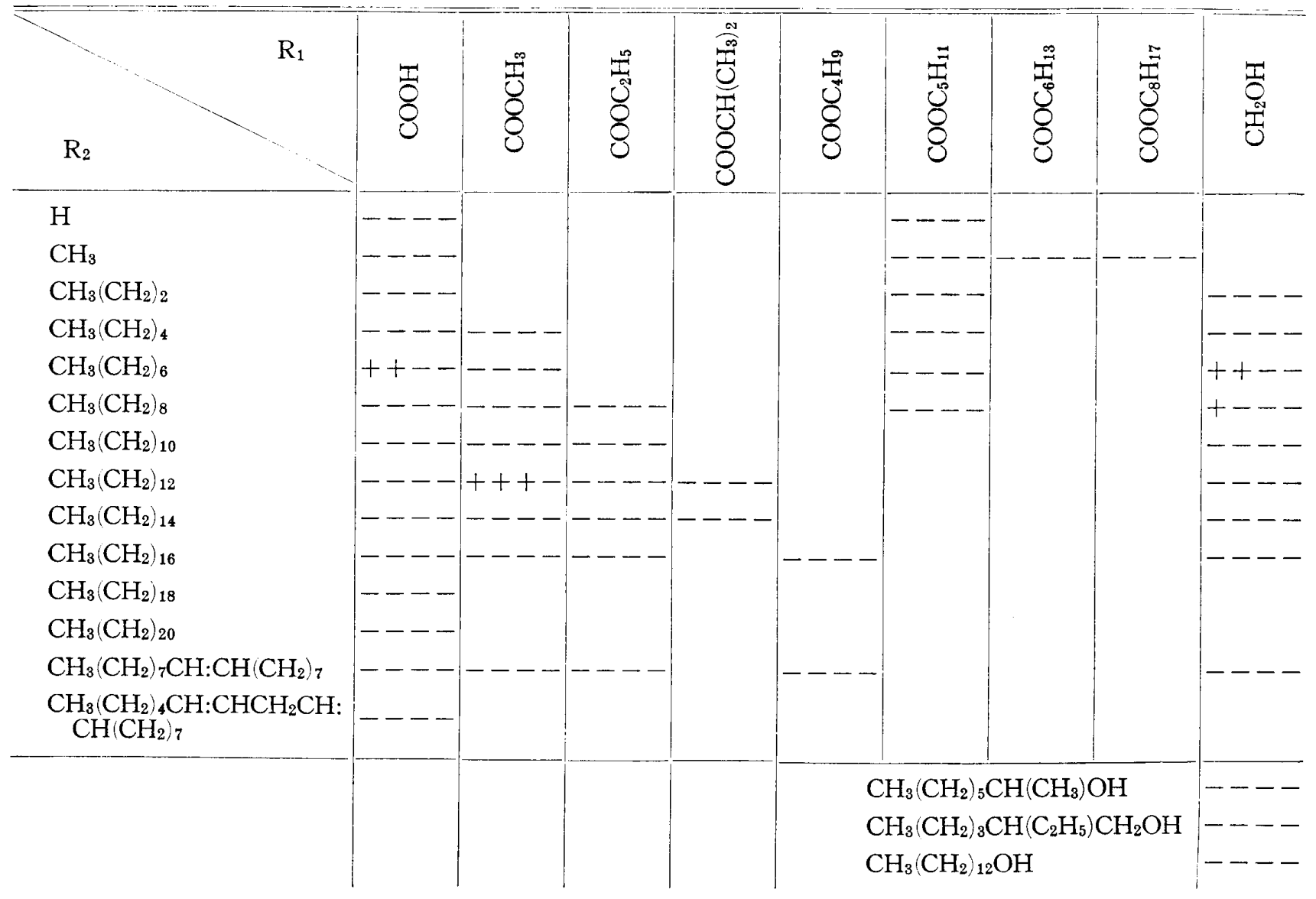


Table 7 Attractiveness of the test compounds for $B$. germanica

Formula $\mathrm{R}_{1}-\mathrm{R}_{2}$

\begin{tabular}{|c|c|c|c|c|c|c|c|c|c|}
\hline 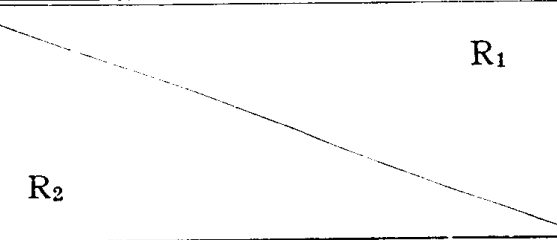 & $\stackrel{1}{8}$ & 穵 & 䓠 & 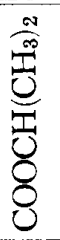 & 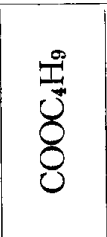 & 焉 & 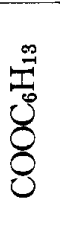 & $\underbrace{\infty}_{8}$ & 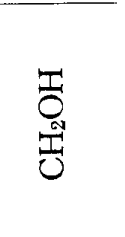 \\
\hline $\begin{array}{l}\mathrm{H} \\
\mathrm{CH}_{3} \\
\mathrm{CH}_{3}\left(\mathrm{CH}_{2}\right)_{2} \\
\mathrm{CH}_{3}\left(\mathrm{CH}_{2}\right)_{4} \\
\mathrm{CH}_{3}\left(\mathrm{CH}_{2}\right)_{6} \\
\mathrm{CH}_{3}\left(\mathrm{CH}_{2}\right)_{8} \\
\mathrm{CH}_{3}\left(\mathrm{CH}_{2}\right)_{10} \\
\mathrm{CH}_{3}\left(\mathrm{CH}_{2}\right)_{12} \\
\mathrm{CH}_{3}\left(\mathrm{CH}_{2}\right)_{14} \\
\mathrm{CH}_{3}\left(\mathrm{CH}_{2}\right)_{16} \\
\mathrm{CH}_{3}\left(\mathrm{CH}_{2}\right)_{18} \\
\mathrm{CH}_{3}\left(\mathrm{CH}_{2}\right)_{20} \\
\mathrm{CH}_{3}\left(\mathrm{CH}_{2}\right)_{7} \mathrm{CH}: \mathrm{CH}\left(\mathrm{CH}_{2}\right)_{7} \\
\mathrm{CH}_{3}\left(\mathrm{CH}_{2}\right)_{4} \mathrm{CH}: \mathrm{CHCH} \mathrm{CH}_{2} \mathrm{CH}\left(\mathrm{CH}_{2}\right)_{7}\end{array}$ & $\begin{array}{rr}1 & (1) \\
1 & (1) \\
4 & (2) \\
24(6) \\
72(12) \\
216(36) \\
216(36) \\
72(12) \\
72(12) \\
4(1) \\
4(4) \\
216(12) \\
24(2)\end{array}$ & $\begin{array}{rr}2 & (2) \\
1 / 2 & (2) \\
8 & (2) \\
24 & (2) \\
216 & (4) \\
216(36) \\
216(6)\end{array}$ & $\begin{array}{rr}36 & (2) \\
216 & (2) \\
72 & (6) \\
216(12) \\
216(12) \\
\\
72(6)\end{array}$ & $\begin{array}{l}36 \\
72\end{array}$ & 216 & $\begin{array}{r}6 \\
2 \\
1 \\
12 \\
72 \\
216\end{array}$ & 72 & 24 & $\begin{array}{rr}6 & (3) \\
1 / 2 & (2) \\
4(12) \\
1(12) \\
24(2) \\
24 & (1) \\
1 & \\
4 & (2)\end{array}$ \\
\hline & & & & \multicolumn{5}{|c|}{$\begin{array}{l}\mathrm{CH}_{3}\left(\mathrm{CH}_{2}\right)_{5} \mathrm{CH}\left(\mathrm{CH}_{3}\right) \mathrm{OH} \\
\mathrm{CH}_{3}\left(\mathrm{CH}_{2}\right)_{3} \mathrm{CH}\left(\mathrm{C}_{2} \mathrm{H}_{5}\right) \mathrm{CH}_{2} \mathrm{OH} \\
\mathrm{CH}_{3}\left(\mathrm{CH}_{2}\right)_{12} \mathrm{OH}\end{array}$} & $\begin{array}{l}1 \\
2 \\
6\end{array}$ \\
\hline
\end{tabular}

Table 8 Feeding response of $B$. germanica to the spots treated with the test compounds Formula $\mathrm{R}_{1}-\mathrm{R}_{2}$

\begin{tabular}{|c|c|c|c|c|c|c|c|c|c|}
\hline $\mathrm{R}_{2}$ & $\stackrel{1}{8}$ & 寗 & 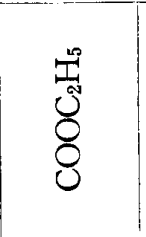 & 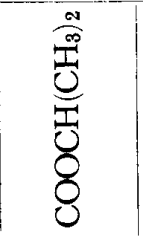 & 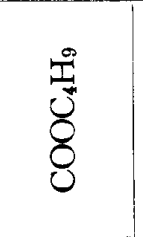 & $\frac{7}{8}$ & $\underbrace{\infty}$ & 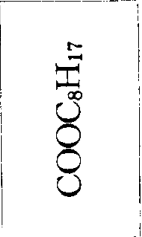 & 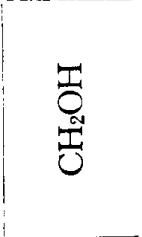 \\
\hline $\begin{array}{l}\mathrm{H} \\
\mathrm{CH}_{3} \\
\mathrm{CH}_{3}\left(\mathrm{CH}_{2}\right)_{2} \\
\mathrm{CH}_{3}\left(\mathrm{CH}_{2}\right)_{4} \\
\mathrm{CH}_{3}\left(\mathrm{CH}_{2}\right)_{6} \\
\mathrm{CH}_{3}\left(\mathrm{CH}_{2}\right)_{8} \\
\mathrm{CH}_{3}\left(\mathrm{CH}_{2}\right)_{10} \\
\mathrm{CH}_{3}\left(\mathrm{CH}_{2}\right)_{12} \\
\mathrm{CH}_{3}\left(\mathrm{CH}_{2}\right)_{14} \\
\mathrm{CH}_{3}\left(\mathrm{CH}_{2}\right)_{16} \\
\mathrm{CH}_{3}\left(\mathrm{CH}_{2}\right)_{18} \\
\mathrm{CH}_{3}\left(\mathrm{CH}_{2}\right)_{20} \\
\mathrm{CH}_{3}\left(\mathrm{CH}_{2}\right)_{7} \mathrm{CH}: \mathrm{CH}\left(\mathrm{CH}_{2}\right)_{7} \\
\mathrm{CH}_{3}\left(\mathrm{CH}_{2}\right)_{4} \mathrm{CH}: \mathrm{CHCH} 2 \mathrm{CH}: \\
\quad \mathrm{CH}\left(\mathrm{CH}_{2}\right)_{7}\end{array}$ & $\begin{array}{l}---- \\
---- \\
---- \\
+--- \\
++++ \\
+--- \\
+--- \\
---- \\
---- \\
---- \\
---- \\
---- \\
++-- \\
++-\end{array}$ & $\begin{array}{l}---- \\
---- \\
---- \\
---- \\
+++- \\
---- \\
----\end{array}$ & $\mid \begin{array}{l}---- \\
---- \\
---- \\
++-- \\
+--- \\
---\cdots\end{array}$ & $\begin{array}{l}---- \\
----\end{array}$ & ---- & $\begin{array}{l}---- \\
---- \\
---- \\
---- \\
---- \\
----\end{array}$ & ---- & ---- & $\begin{array}{l}---- \\
---- \\
---- \\
---- \\
---- \\
---- \\
---- \\
---- \\
++++\end{array}$ \\
\hline & & & & & \multicolumn{4}{|c|}{$\begin{array}{l}\mathrm{CH}_{3}\left(\mathrm{CH}_{2}\right)_{5} \mathrm{CH}\left(\mathrm{CH}_{3}\right) \mathrm{OH} \\
\mathrm{CH}_{3}\left(\mathrm{CH}_{2}\right)_{3} \mathrm{CH}\left(\mathrm{C}_{2} \mathrm{H}_{5}\right) \mathrm{CH}_{2} \mathrm{OH} \\
\mathrm{CH}_{3}\left(\mathrm{CH}_{2}\right)_{12} \mathrm{OH}\end{array}$} & $\begin{array}{l}---- \\
---- \\
----\end{array}$ \\
\hline
\end{tabular}


the spot of oleyl alcohol heavily but the other two species not.

\section{General consideration}

The results described above suggest thet the starved cockroaches are attracted to many kinds of fat soluble substances which include at least three groups of compounds, fatty acids, their esters, and related alcohols. This may be related to the omnivorous food preference of the three species. The results also suggest that in each homologous group of effective compounds, there is an optimum range of molecular weights for attractiveness, and the ranges are somewhat different among the groups of compounds, perhaps reflecting the difference of the vapor pressure and hence of volatility. There seems to be some specific responses of the cockroaches to several compounds, though the lack of specificity of most of the attracting substances and of the feeding stimulative ones are demonstrated among the three species.

\section{ACKNOWLEDGEMENT}

The author wishes to express his hearty thanks to Dr. Syoziro Asahina, Department of Medical Entomology, National Institute of Health, Tokyo, for his kind help in the course of the work.

\section{SUMMARY}

Some fatty acids, their esters, and related alcohols were assayed by a filter paper method for the attractive and feeding stimulative effect on the three species of cockroaches, Periplaneta americana, P. fuiiginosa, and Blattella germanica.

The results suggest that the starved cockroaches are attracted to many kinds of fat soluble substances which include at least above mentioned three groups of compounds. There seems to be optimum ranges of molecular weights for attractiveness in homologous groups of the compounds. The most effective saturated free fatty acids in gathering the insects on the spots treated with them were n-caproic, ncaprylic, n-capric, and lauric acid. Oleic acid, one of unsaturated fatty acids, was also highly attractive. The most effective attractants in esters were methyl myristate, ethyl myristate, methyl palmitate, and ethyl palmitate. Saturated normal alcohols with 8 to 14 carbon atoms were also attractive especially for $P$. americana, and $P$. fuliginosa. Oleyl alcohol was especially attractive for B. germanica.

A few of the attractive compounds also showed the feeding stimulative effect, but many others were less or not effective in eliciting feeding responses in the three species at a dose level of about $250 \mu \mathrm{g}$ per spot on the paper, despite of their long time exposure to the insects. The most effective feeding stimulants were $\mathrm{n}$-caprylic acid and methyl myristate. Oleyl alcohol was especially stimulative for $B$. germanica, but not for the others.

There observed a few species-specific responses to some compounds, though the lack of specificity of most of the attracting compounds and feeding stimulative ones among the three species was demonstrated.

\section{REFERENCES}

1) Dethier, V. G., Brown, L. B. and Smith, C. N. (1960): The designation of chemicals in terms of the responses they elicit from insects. J. econ. Ent., 53: 134-136. - 2) Loschiavo, S. R. (1965): The chemosensory influence of some extracts of brewer's yeast and cereal products on the feeding behaviours of the confused flour beetle, Tribolium confusum (Coleoptera: Tenebrionidae). Ann. Entomol. Soc. Amer., 58 (4) : 576-588. - 3) Noguchi, K. (1961): Cockroaches in a typewriting room. Jap. J. Sanit. Zool., 12 (2) : 118. - 4) Ogata, K. and M. Mihara (1962): Observations on the efficiency of the so called "butter-trap" in trapping the German cockroach, Blattella germanica Linné. Jap. J. Sanit. Zool., 13 (4) : 262-267. - 5) Tsuji, H. (1965) : Studies on the behaviour pattern of feeding of three species of cockroaches, Blattella germanica (L.), Periplaneta americana L., and P. fuliginosa S., with special references to their responses to some constituents of rice bran and some carbohydrates. Jap. J. Sanit. Zool., 16 (4) : 255-262.

\section{摘 要 \\ いくつかの脂肪酸およびその関連物質の ゴキブリ 3 種に対する誘引作用と 摂食行動誘起作用}

前報（辻，1965)では，雑食性のゴキブリにおいても， その対食物行動の物質的基として, 脂溶性の誘引物質お 上び攝食行動誘起物質，メタノールまたは水に溶ける攝 食行動誘起物質があり，数種の糖およびその関連物質が 
後者の一部であることを明らかにした。

今回の実験では脂溶性の物質, 特に天然の脂肪酸の一 部，および若干の関連物質(エステル，アルコール)につ いて，ワモンゴキブリ，クロゴキブリ，チャバネゴキブ リの成虫および老齢幼虫に対する誘引作用と攝食行動誘 起作用を前報の濾紙法およびその変法で調查した。その 結果，上記 3 種の飢えた個体は少くとも脂肪酸，その.エ ステルおよび関連アルコールの各グループのうち夫々適 当な炭素数をもつかなり多種類の物質に誘引され，それ らの一部は摂食行動誘起作用もあることが示された。こ れらの効果のためには, 各類似化合物グループ毎に最適 分子量があるようである。

誘引作用は, $\mathrm{n}$-カプロン酸, $\mathrm{n}$-カプリル酸, $\mathrm{n}$-カプリ ン酸, ラウリン酸, オレイン酸, メチルミリステート,
エチルミリステート，メチルパルミテート，エチルパル ミテート, n-オクチルアルコール, n-デシルアルコー ル, $\mathrm{n}$-ドデシルアルコール, $\mathrm{n}$-テトラデシルアルコー ル，オレイルアルコールで強かつたが，種により若干の 反応差があつた。

掑食行動誘起作用は, n-カプリル酸, メチルミリステ 一トで特に強かつた. また，オレイルアルコールはチャ バネゴキブリに対してのみ強い作用を示した.

以上の結果は，ゴキブリ類に対して多種類の脂溶性誘 引物質および提食行動誘起物質があり，しかもそれらの 多くがどの種類にも共通であることを暗示するものであ るが，一方若干の物質に対しては各ゴキブリの示す反応 は種特異的であることをも示している. 